\title{
PENGARUH ENTERPRISE RISK MANAGEMENT (ERM) TERHADAP NILAI PERUSAHAAN PADA PERUSAHAAN MANUFAKTUR YANG TERDAFTAR DI BURSA EFEK
}

\author{
Iswajuni ${ }^{* 1}$, Soegeng Soetedjo ${ }^{* 2}$ and Arina Manasikana ${ }^{\# 3}$ \\ ${ }^{*}$ Sekretaris Badan Pengawas Internal Universitas Airlangga \\ ${ }^{{ }_{2}}$ Ketua Badan Pengawas Internal Universitas Airlangga \\ $\#^{3}$ Sarjana Akuntansi, Fakultas Ekonomi dan Bisnis Universitas AIrlangga \\ \# Kampus C Mulyorejo, Surabaya, Indonesia \\ E-mail: yuyun_iswahyuni@yahoo.com
}

\begin{abstract}
Abstrak
Enterprise Risk Management (ERM) dapat memberikan nilai tambah bagi perusahaan dengan memudahkan manajemen dalam mengendalikan beragam jenis risiko yang disebabkan adany a kondisi ketidakpastian dengan mengintegrasikan semua jenis risiko yang timbul menggunakan alat dan teknik terpadu, dan kemudian mengkoordinasikan kegiatan dari manajemen risiko kepada seluruh unit operasi dalam suatu organisasi sehingga semua jenis risiko dapat diminimalkan. Penerapan Enterprise Risk Management (ERM) dipandang sebagai sinyal positif oleh investor sehingga respon positif yang diberikan investor dapat memberikan nilai tambah bagi perusahaan. Penelitian ini bertujuan untuk mengetahui pengaruh Enterprise Risk Management (ERM) dengan variabel kontrol yang terdiri dari ukuran perusahaan, ROA, dan kepemilikan manajerial terhadap nilai perusahaan. Populasi penelitian perusahaan manufaktur yang terdaftar di Bursa Efek Indonesia pada periode 2010-2013. Metode yang digunakan dalam penelitian ini adalah Regresi Linear Berganda-Ordinary Least Square (OLS) dan uji hipotesis yang menggunakan uji -t untuk menguji koefisien regresi dengan tingkat signifikan 5\%. Hasil penelitian menunjukkan bahwa Enterprise Risk management (ERM) berpengaruh positif signifikan terhadap nilai perusahaan. Ukuran perusahaan berpengaruh positif signifikan terhadap nilai perusahaan. ROA berpengaruh positif signifikan terhadap nilai perusahaan. Sedangkan kepemilikan manajerial memiliki pengaruh negatif signifikan terhadap nilai perusahaan.
\end{abstract}

Kata kunci: Enterprise Risk Management, Ukuran Perusahaan, ROA, Kepemilikan Manajerial, dan Nilai Perusahaan Abstract

Enterprise Risk Management (ERM) create value added for the company by facilitate management in controlling various risk which caused uncertainties condition by integrating all types of risk using integrated tools and techniques, and then coordinate the activities of risk management to all operating unit within an organization so that all types of risk can be minimized. The implementation of Enterprise Risk Management (ERM ) seen as a positive signals by investor, so that positive response which given by investors can increase value of the firm. The objectives of this research is to identify the effect of Enterprise Risk Management (ERM) and firm size, ROA, and managerial ownership as control variables on firm value that is proxied by Tobin's Q. Population of this research was manufacturing companies listed in Indonesia Stock Exchange (IDX) in 2010-2013. The used method in this research is Multiple Linear Regression-Ordinary Least Square (OLS) and hypotheses testing using t-test to test the regression coefficients with level of significant of 5\%.. The results showed that Enterprise Risk Management (ERM) hassignificant positive effect on the firm value. Size of the company has significant positive effect on the firm value. ROA has significant positive effect on the firm value. While the managerial ownership has significant negative effect on the firm value.

Keywords: Enterprise Risk Management, Firm Size, ROA, Managerial Ownership, and Firm Value 


\section{PENDAHULUAN}

Risiko merupakan unsur yang melekat dalam kegiatan bisnis suatu perusahaan dan termasuk dalam aktivitas bisnis (Andono, 2013). Menurut Andono (2013), ada berbagai macam risiko yang dihadapi oleh perusahaan, diantaranya adalah risiko keuangan, risiko operasional, risiko strategis, risiko eksternal dan risiko lainnya yang mungkin muncul dalam menjalankan aktivitas perusahaan. Untuk menghadapi keadaan yang ada, perusahaan perlu menyediakan perangkat manajemen yang dapat mengelola risiko (Widjaya \& Sugiarti, 2013).

Bertinetti et al. (2013), Hoyt and Liebenberg (2011) Hoyt and Lienbenberg (2011), ), Li et al. (2014).menghubungkan antara Enterprise Risk Management (ERM) dengan nilai perusahaan menemukan bahwa penerapan ERM memiliki dampak signifikan positif pada nilai perusahaan. Hasil empiris mendukung bahwa ERM akan meningkatkan nilai perusahaan sebesar 3,6\%-17\% lebih tinggi dari perusahaan yang tidak menerapkan ERM.

Masalah dalam penelitian ini adalah apakah Enterprise Risk Management (ERM) berpengaruh terhadap nilai perusahaan?

Tujuan penelitian ini adalah untuk menguji pengaruh Enterprise Risk Management (ERM) terhadap nilai perusahaan Hasil penelitian ini diharapkan dapat memberikan pemahaman dan referensi baru tentang pentingnya ERM (Enterprise Risk Management) pada perusahaan dan juga memberikan gambaran tentang pengaruh ERM (Enterprise Risk Management) terhadap nilai perusahaan.

\section{Enterprise Risk Management (ERM)}

Menurut Hanafi (2009), risiko dapat dikelompokkan menjadi dua macam, yaitu antara lain: Risiko murni, Risiko aset fisik, Risiko legal, Risiko spekulatif, dan Risiko pasar, Risiko kredit, Risiko likuiditas, dan Risiko operasional dan mengakibatkan kegagalan rugian seperti kegagalan sistem, human error, pengendalian dan prosedur yang ujung-ujungnya mengganggu capaian tujuan.

Menurut COSO, Enterprise Risk Management adalah sebuah proses yang dipengaruhi oleh manajemen, board of directors, dan personel lainnya yang dijalankan dalam penentuan strategi dan mencakup organisasi secara keseluruhan, didesain untuk mengidentifikasi kejadian-kejadian yang berpotensi untuk mempengaruhi organisasi, dan mengelola risiko, serta menyediakan keyakinan yang memadahi terkait pencapaian tujuan organisasi.

COSO ERM framework membagi objectives atau tujuannya menjadi empat kategori besar, yaitu strategic, operations, reporting, dan compliance. Dengan mengadopsi pendekatan yang sistematis dan konsisten untuk mengelola semua risiko yang dihadapi perusahaan, Enterprise Risk Management (ERM) dianggap menurunkan risiko kegagalan suatu perusahaan secara keseluruhan, dan dengan demikian dapat meningkatkan kinerja dan nilai perusahaan (Gordon et al., 2009).

\section{Nilai Perusahaan (Firm Value)}

Nilai perusahaan menggambarkan harga yang bersedia dibayar investor (Prasetyorini, 2013). Peningkatan kesejahteraan pemilik dan pemegang saham dapat tercermin melalui peningkatan harga saham pasar (Nurlela dan Islahuddin, 2008). Pada penelitian ini, nilai perusahaan diukur menggunakan rasio Tobin's Q yang menilai perusahaan dengan mengukur nilai perusahaan berdasarkan harga pasar.

$Q=\frac{(\Sigma \text { Outstanding Shares } x \text { Closing price })+\text { Total Liabilities }}{\text { Total Assets }}$

Teori Agensi

Prinsip teori agensi adalah hubungan dua belah pihak yaitu pihak principal dan pihak agen. Pada perusahaan besar dan go publik, keberadaan antara pemilik dan manajemen terpisah terutama dalam hal operasional perusahaan mencerminkan ekspektasi masa depan investor (Lin et al.,2012). (Sudiyatno \& Puspitasari, 2010). Hoyt and Liebenberg (2011) memberikan rumus untuk menghitung Tobin's Q sebagai berikut: Dalton et al. (2007) mengungkapkan bahwa teori keagenan dapat menyebabkan "managerial mischief" karena perbedaan kepentingan antara pihak principal dan agen.

\section{Kepemilikan Manajerial}

Besarnya kepemilikan saham yang dimiliki oleh direksi dan komisaris perusahaan menunjukkan seberapa besar usaha mereka dalam mensejajarkan kepentingannya dengan para pemegang saham. Kepemilikan manajerial dinyatakan dengan rumus:

$$
\text { OWN }=\frac{\sum \text { Saham yang Dimiliki Manajemen }}{\sum \text { Saham yang Beredar }} \times 100 \%
$$

\section{Ukuran Perusahaan (Size)}

Ukuran perusahaan terbagi dalam tiga kategori, yaitu perusahaan besar (large firm), perusahaan menengah (medium-size), dan perusahaan kecil (smaal frim). Ukuran atau besarnya asset yang dimiliki oleh perusahaan. Ukuran perusahaan dinyatakan dengan rumus:

UkuranPerusahaan $=\operatorname{Ln}$ (Totalaset) 


\section{Profitabilitas}

Profitabilitas yang tinggi akan memacu perusahaan tumbuh dan berkembang dan begitu juga sebaliknya (Pakpahan, 2010). Rasio profitabilitas dapat dicerminkan dengan Return On Assets (ROA). Rasio ini dapat dinyatakan dalam berbagai cara, yang paling umum adalah:

ROA $=\frac{\text { Laba Bersih }}{\text { Total Aset }}$

Pengaruh Enterprise Risk Management terhadap Nilai Perusahaan

Penelitian dilakukan oleh (Hoyt \& Liebenberg, 2011) Bertinetti et al. (2013) Hasil penelitian ini menunjukkan adanya pengaruh positif antara Enterprise Risk Management dengan nilai perusahaan.

\section{KAJIAN PUSTAKA}

Kami merujuk 8 penelitian mulai tahun 2009 sampai dengan 2015 yang menguji pengaruh ERM antara lain adalah Gordon et al. (2009), Pagach and Warr (2010), Hoyt and Liebenberg (2011), Tahir and Razali (2011), Waweru dan Kisaka (2013), Bertinettiet al. (2013), Li et al. (2014), Sanjaya and Linawati (2015) terhadap nilai perusahaaan yang pada umumnya menyatakan terdapat pengaruh positif.

\section{Kerangka Konseptual}

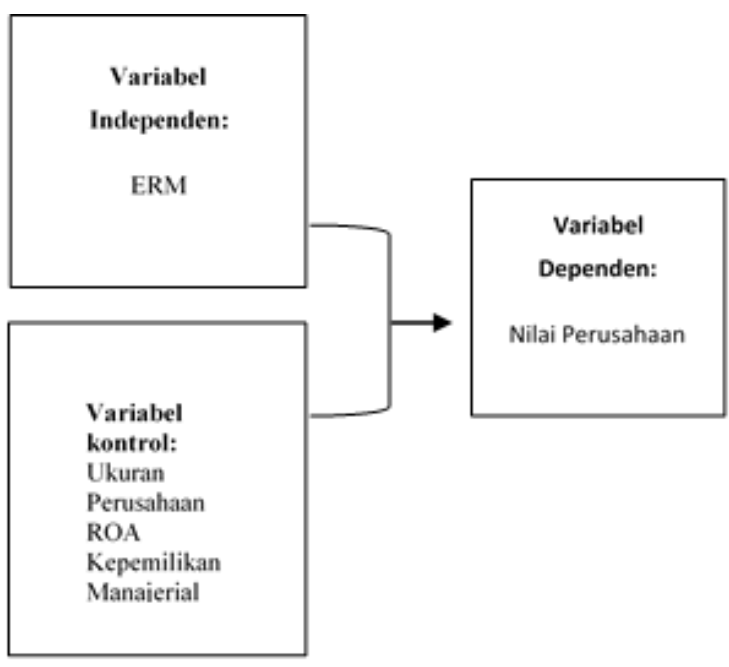

Gambar 1. Kerangka Konseptual

Sumber: Data yang diolah

\section{METODE PENELITIAN}

\subsection{Pendekatan Penelitian}

Penelitian ini dilakukan dengan menggunakan pendekatan kuantitatif yang menitik beratkan pada pengujian hipotesis.

\subsection{Identifikasi Variabel}

Variabel dependen dalam penelitian ini adalah nilai perusahaan, sedangkan variabel independen adalah Enterprise Risk Management (ERM). Penelitian ini juga menggunakan variabel kontrol yang terdiri dari ukuran perusahaan, ROA, dan kepemilikan manajerial.

\subsection{Definisi Operasional}

\subsubsection{Nilai Perusahaan (Firm Value)}

Nilai perusahaan merupakan variabel dependen dalam penelitian ini. Nilai perusahaan merupakan gambaran dari kondisi kemakmuran pemilik. . Nilai perusahaan merupakan nilai yang diberikan oleh pasar keuangan (harga pasar) yang bersedia dibayar oleh calon pembeli (investor). Penelitian ini menggunakan rasio Tobin's Q yang dihitung dengan rumus sebagai berikut:

\section{( $\Sigma$ Outstanding Shares $\times$ Closing Price) + Total Liabilities Total}

\section{Assets}

\subsubsection{Enterprise Risk Management (ERM)}

Variabel independen dalam penelitian ini adalah Enterprise Risk Management (ERM). Enterprise Risk Management (ERM) merupakan suatu sistem pengelolaan risiko terintegrasi untuk tujuan meningkatkan nilai perusahaan. Pada penelitian ini, pengungkapan ERM yang tercantum dalam laporan tahunan perusahaan dilakukan dengan pencarian frase yang sama dengan kata berikut, "Enterprise Risk Management", "Chief Risk Officer ", "komite manajemen risiko (Risk Management Committee)" "Komite risiko (Risk Committee)", "Manajemen Risiko Strategis", "Manajemen Risiko Konsolidasi", "Manajemen Risiko Holistik", "Manajemen Risiko Terintegrasi". Enterprise Risk Management diukur dengan variabel dummy, nilai 1 untuk perusahaan yang menerapkan ERM dan 0 untuk yang lainnya.

\subsubsection{Ukuran Perusahaan (Size)}

Ukuran perusahaan menggambarkan besar kecilnya suatu perusahaan yang dapat diukur dengan beberapa cara antara lain total asset, total penjualan, dan total saham dimiliki perusahaan. Pada penelitian ini ukuran perusahaan digambarkan dengan besarnya aset yang dimiliki perusahaan yang diukur dengan total asetatau biasa disebut Ln (Aset) .Rumus perhitungan ukuran perusahaan dapat dituliskan sebagai berikut:

\section{Ukuran Perusahaan $=\operatorname{Ln}($ Total Aset $)$}

\subsubsection{Return On Assets(ROA)}

ROA menunjukkan kemampuan perusahaan dalam menghasilkan laba menggunakan seluh aktiva yang dimiliki perusahaan. ROA adalah rasio antara 
keuntungan bersih terhadap jumlah aset. Data ROA dihitung dengan rumus:

$$
R O A=\frac{\text { Laba Bersih }}{\text { Total Aset }}
$$

Data untuk laba bersih didapat dari laporan laba rugi, sedangkan total aset didapat dari neraca laporan keuangan perusahaan.

\subsubsection{Kepemilikan manajerial}

Kepemilikan Manajerial (insider ownership) adalah sebuah ukuran persentase saham yang dimiliki oleh manajemen seperti, direksi dan komisaris ataupun setiap pihak yang terlibat secara langsung dalam pembuatan keputusan perusahaan. Perhitungan kepemilikan manajerial diproksikan dengan persentase saham yang dimiliki oleh manajemen seperti, direksi dan komisaris. Rumus perhitungan insider ownership dapat dituliskan sebagai berikut:

\section{¿saham yang Dimiliki Manajemen x100\% \\ $\Sigma$ saham yang beredar}

\subsection{Jenis dan Sumber Data}

Jenis data yang dipakai dalam penelitian ini adalah data kuantitatif yaitu jenis data nominal (dummy) dan rasio. Sumber data pada penelitian ini adalah data sekunder yaitu data yang diperoleh dari sumber data laporan keuangan yang sudah diaudit dan laporan tahunan perusahaan manufaktur yang listing di BEI dari periode tahun 2010-2013.Laporan keuangan dan tahunan perusahaan diperoleh dari website BEI yaitu www.idx.com. Selain itu data juga diperoleh dari yahoofinance.

Hipotesis : Enterprise Risk Management (ERM) berpengaruh positif terhadap nilai perusahaan.

\section{Populasi dan Sampel}

Populasi dalam penelitian ini adalah perusahaan manufaktur yang terdaftar di Bursa Efek Indonesia (BEI) tahun 2010-2013. Dari seluruh perusahaan manufaktur yang terdaftar di Bursa Efek Indonesia (BEI) periode 2010-2013 diperoleh sampel dari masing-masing periode sebagai berikut:

Tabel 1 Kriteria dan Jumlah Sampel Penelitian

\begin{tabular}{|c|l|c|c|c|c|}
\hline \multicolumn{2}{|c|}{ Kriteria } & \multicolumn{3}{c|}{ Jumlah Sampel } & $\begin{array}{c}\text { 1001 } \\
1,58\end{array}$ \\
\cline { 3 - 6 } & 2010 & 2011 & 2012 & $\begin{array}{c}2013 \\
4.1\end{array}$ \\
\hline 1. & $\begin{array}{l}\text { Populasi total perusahaan } \\
\text { manufaktur yang terdaftar di } \\
\text { BEI }\end{array}$ & 125 & 129 & 132 & $\begin{array}{c}\text { Dazri } \\
\text { dand }\end{array}$ \\
\hline
\end{tabular}

\begin{tabular}{|r|l|c|c|c|c|}
\hline 2. & $\begin{array}{l}\text { Perusahaan yang tidak } \\
\text { terdaftar di BEI selama } \\
\text { periode penelitian }\end{array}$ & $(2)$ & (3) & (1) & (1) \\
\hline 3. & $\begin{array}{l}\text { Laporan keuangan dan } \\
\text { laporan tahunan } \\
\text { tidaklengkap selama periode } \\
\text { 2010-2013 }\end{array}$ & $(0)$ & $(4)$ & $(7)$ & $(12)$ \\
\hline 4. & $\begin{array}{l}\text { Perusahaan yang tidak } \\
\text { menyediakan data harga } \\
\text { saham diakhir tahun (closing } \\
\text { price) secara lengkap selama } \\
\text { periode 2010-2013 }\end{array}$ & $(1)$ & $(0)$ & $(0)$ & $(0)$ \\
\hline 5. & $\begin{array}{l}\text { Satuan mata uang selain } \\
\text { rupiah selama periode } \\
\text { 2010-2013 }\end{array}$ & $(10)$ & $(11)$ & $(24)$ & $(26)$ \\
\hline Total Sampel & 112 & 111 & 100 & 98 \\
\hline
\end{tabular}

Sumber: Data Olahan

\section{Teknik Analisis}

Teknik analisis yang digunakan untuk menguji dan membuktikan hipotesis dalam penelitian ini adalah model multiple regression (regresi berganda) dengan bantuan aplikasi Statistical Product and Service Solutions (SPSS) 18.

\section{HASIL DANPEMBAHASAN}

Analisis regresi digunakan untuk menguji pengaruh variabel bebas terhadap variabel terikat. Penelitian ini menggunakan analisis regresi berganda untuk mengetahui pengaruh Ernterprise Risk Management (ERM), size, profitabilitas (ROA), dan kepemilikan manajerial terhadap nilai perusahaan. Berikut ini adalah hasil regresi tersebut:

Tabel 2. Hasil Koefisien Regresi Coefficients ${ }^{\mathrm{a}}$

\begin{tabular}{|ll|r|r|r|r|r|}
\hline Model & \multicolumn{2}{|c|}{$\begin{array}{c}\text { Unstandardized } \\
\text { Coefficients }\end{array}$} & $\begin{array}{c}\text { Standardize } \\
\mathrm{d} \\
\text { Coefficients }\end{array}$ & \multirow{2}{*}{$\mathrm{t}$} & \multirow{2}{*}{ Sig. } \\
\cline { 2 - 5 } & \multicolumn{1}{|c|}{ B } & \multicolumn{1}{|c|}{ Std. Error } & \multicolumn{1}{c|}{ Beta } & & \\
\hline 1 & (Constant) & $-1,783$ & 0,595 & & $-2,998$ & 0,003 \\
& ERM & 0,348 & 0,091 & 0,175 & 3,838 & 0,000 \\
& Size & 0,071 & 0,022 & 0,159 & 3,285 & 0,001 \\
& ROA & 1,587 & 0,231 & 0,304 & 6,868 & 0,000 \\
& Kep. & $-1,768$ & 0,421 & $-0,179$ & $-4,197$ & 0,000 \\
Manajerial & & & & & \\
\hline
\end{tabular}

Sumber: Lampiran 3

Berdasarkan hasil perhitungan regresi di atas, dapat dirumuskan persamaan regresi sebagai berikut:

$$
\begin{aligned}
& \text { n's } \mathrm{Q}=-1,783+0,384 \text { ERMit + 0,071 Sizeit + } \\
& 7 \text { ROAit }-1,768 \text { Kep. } \\
& \text { Koefisien Determinasi dan Koefisien Korelasi }
\end{aligned}
$$

\section{Koefisien Determinasi dan Koefisien Korelasi}

hasil uji regresi dapat diketahui koefisien korelasi eterminasi sebagai berikut: 
Tabel3HasilKoefisienDeterminasidanKorelasi

\begin{tabular}{|l|l|l|l|l|}
\hline \multicolumn{1}{|c|}{ Model } & \multicolumn{1}{|c|}{$\mathrm{R}$} & $\mathrm{R}$ Square & $\begin{array}{c}\text { Adjusted } \mathrm{R} \\
\text { Square }\end{array}$ & $\begin{array}{l}\text { Atd. Enror of } \\
\text { the Estimate }\end{array}$ \\
\hline 1 & $0,530^{\mathrm{2}}$ & 0,280 & 0,274 & 0,60226 \\
\hline
\end{tabular}

Sumber: Data yang diolah

\subsection{Pengujian Hipotesis}

Pengujian yang dilakukan dalam penelitian ini adalah uji parsial atau uji t.

Tabel 4. Hasil Uji t Coefficientsa

\begin{tabular}{|c|c|c|c|c|c|c|}
\hline \multirow{3}{*}{\multicolumn{2}{|c|}{ Model }} & \multirow{2}{*}{\multicolumn{2}{|c|}{$\begin{array}{l}\text { Unstandardized } \\
\text { Coefficients }\end{array}$}} & \multirow{3}{*}{$\begin{array}{c}\begin{array}{c}\text { Standardize } \\
\mathrm{d}\end{array} \\
\text { Coefficients } \\
\text { Beta } \\
\end{array}$} & \multirow{3}{*}{$t$} & \multirow{3}{*}{ Sig. } \\
\hline & & & & & & \\
\hline & & B & Std. Error & & & \\
\hline \multirow[t]{5}{*}{1} & (Constant) & $-1,783$ & 0,595 & & $-2,998$ & 0,003 \\
\hline & ERM & 0,348 & 0,091 & 0,175 & 3,838 & 0,000 \\
\hline & Size & 0,071 & 0,022 & 0,159 & 3,285 & 0,001 \\
\hline & ROA & 1,587 & 0,231 & 0,304 & 6,868 & 0,000 \\
\hline & $\begin{array}{l}\text { Kep. } \\
\text { Manajerial }\end{array}$ & $-1,768$ & 0,421 & $-0,179$ & $-4,197$ & 0,000 \\
\hline
\end{tabular}

Sumber: Lampiran 4

Berdasarkan tabel 4 diketahui nilai uji $\mathrm{t}$ variabel Enterprise Risk Management (ERM) terhadap nilai perusahaan adalah sebesar 3,838 dengan tingkat signifikansi 0,000 . Tingkat signifikan pada variabel ini lebih kecil dari 5\% maka HO ditolak sehingga dapat disimpulkan bahwa Enterprise Risk Management (ERM) memiliki pengaruh positif yang signifikan terhadap nilai perusahaan.

Berdasarkan tabel 4 nilai uji t variabel kontrol ukuran perusahaan (size) terhadapnilai perusahaan adalah sebesar 3,285 dengan nilai signifikansi 0,001 sehingga disimpulkan bahwa ukuran perusahaan (size) memiliki pengaruh positif yang signifikan terhadap nilai perusahaan.

Berdasarkan tabel 4 nilai uji $\mathrm{t}$ variabel kontrol profitabilitas (ROA) terhadap nilai perusahaan adalah sebesar 6,868 dengan nilai signifikansi 0,000 sehingga disimpulkan bahwa profitabilitas (ROA) memiliki pengaruh positif yang signifikan terhadap nilai perusahaan.

Berdasarkan tabel 4 nilai uji $\mathrm{t}$ variabel kontrol kepemilikan manajerialterhadap nilai perusahaan adalah sebesar $-4,197$ dengan nilai signifikansi 0,000 sehingga disimpulkan bahwa kepemilikan manajerial memiliki pengaruh negatif yang signifikan terhadap nilai perusahaan.

\subsection{Pembahasan}

Pengaruh Enterprise Risk Management (ERM) Terhadap Nilai Perusahaan

Berdasarkan hasil analisis yang dilakukan, hasil penelitian menunjukkan bahwa variabel Enterprise Risk Management (ERM) berpengaruh positif terhadap nilai perusahaan Hasil ini konsisten dengan penelitian Hoyt and Liebenberg (2011), Bertinetti et al. (2013). Adanya pengelolaan risiko yang lebih baik dengan diterapkannya Enterprise Risk Management (ERM) pada suatu perusahaan turut menentukan tingkat kepercayaan investor.

\section{Pengaruh Ukuran Perusahaan (Size) Terhadap Nilai Perusahaan}

Ukuran perusahaan berpengaruh positif signifikan terhadap nilai perusahaan. Hasil ini mendukung penelitian yang telah dilakukan oleh Nuraina (2012) dan Sujoko and Soebiantoro (2007).

\section{Pengaruh Profitabilitas (ROA) Terhadap Nila Perusahaan}

Hasil penelitian ini mendukung penelitian sebelumnya yang dilakukan oleh Murhadi (2008) dan Sujoko and Soebiantoro (2007)yang menemukan adanya pengaruh positif signifikan antara profitabilitas (ROA) dengan nilai perusahaan.

\section{Pengaruh Kepemilikan Manajerial Terhadap Nilai Perusahaan}

Kepemilikan manajerial mempunyai koefisien negatif dan signifikan yang berarti kepemilikan manajerial yang tinggi akan menurunkan nilai perusahaan. Hal ini di dukung oleh hipotesis entrenchment yang dikemukakan oleh Stulz (1980) menyatakan bahwa kepemilikan manajerial yang semakin tinggi akan menyebabkan penurunan nilai perusahaan.

\section{SIMPULAN DAN SARAN}

\section{Simpulan}

Berdasarkan pada uraian hasil analisis data dan pembahasan pada uraian sebelumnya, maka simpulan dari penelitian ini adalah meskipun penerapan Enterprise Risk Management (ERM) di Indonesia masih sedikit, namun dapat membuktikan bahwa ERM berpengaruh positif terhadap nilai perusahaan (firm value). 
Saran

Berdasarkan hasil penelitian dan kesimpulan yang diperoleh, ada beberapa saran yang dapat diberikan sebagai berikut: Untuk perusahaan sebaiknya menerapkan Enterprise Risk Management (ERM) dalam mengelola risiko bisnis perusahaan agar dapat memaksimumkan nilai perusahaan.

\section{DAFTAR PUSTAKA}

Andono, F. A. 2013. Penerapan Enterprise Risk Management Dalam Rangka Meningkatkan Efektifitas Kegiatan Operasional "Cv. Anugerah Berkat Calindojaya”. Calyptra: Jurnal Ilmiah Mahasiswa Universitas Surabaya, 2(1).

Anggraini, F. R. R. 2006. Pengungkapan informasi sosial dan faktor-faktor yang mempengaruhi pengungkapan informasi sosial dalam laporan keuangan tahunan (Studi empiris pada perusahaan-perusahaan yang terdaftar bursa efek Jakarta). Simposium Nasional Akuntansi, 9: 23-26.

Antari, D., dan I Made Dana. 2013. Pengaruh Struktur Modal, Kepemilikan Manajerial, Dan Kinerja Keuangan Terhadap Nilai Perusahaan. E-Jurnal Manajemen Universitas Udayana, 2(3).

Bertinetti, G., Cavezzali, and Gardenal. 2013. The effect of the enterprise risk management implementation on the firm value of European companies. Department of Management, Università Ca'Foscari Venezia Working Paper(10).

Chen, C. R., Guo, and Mande. 2003. Managerial ownership and firm valuation: Evidence from Japanese firms. Pacific-Basin Finance Journal, 11(3): 267- 283.

Dalton, D. 2007. The Fundamental Agency Problem and Its Mitigation: Independence, Equity, and the Market for Corporate Control. The academy of management annals, 1(1): 1-64.

Ghozali, I. 2006. Aplikasi Analisis Multivariative dengan Program SPSS. Semarang: BP UNDIP.

Gordon, L., Loeb, and Tseng. 2009. Enterprise risk management and firm performance: A contingency perspective. Journal of Accounting and Public Policy, 28(4): 301-327.

Gujarati, D. N., and Porter. 2012. Dasar-Dasar Ekonometrika (5 ed.). Jakarta: Salemba Empat.

Gusaptono, R. H. 2012. Faktor-Faktor yang Mendorong Penciptaan Nilai Perusahaan di BEI. Buletin Ekonomi.

Hanafi, M. M. 2009. Manajemen Risiko (Kedua ed.). Yogyakarta: UPP STIM YKPN.

Hoyt, R. E., and Liebenberg. 2011. The value of enterprise risk management. Journal of Risk and Insurance, 78(4): 795-822.

Indahningrum, R. P., dan Handayani. 2009. Pengaruh Kepemilikan Manajerial, Kepemilikan
Institusional, Dividen, Pertumbuhan Perusahaan, Free Cash Flow dan Profitabilitas terhadap Kebijakan Hutang Perusahaan. Jurnal Bisnis dan Akuntansi, 11(3): 189-207.

Iturriaga, F. J. L., and Sanz. 2000. Ownership Structure, Corporate Value and Firm Investment: A Spanish Firms Simultaneous Equations Analysis: Working Paper.

Jehnsen, M. C., W.H. Meckling. 1976. Theory of The Firm: Managerial Behavior, Agency Cost And Ownership Structure. Journal of Financial Economic 3: 305-306.

Lam, J. 2000. Enterprise-wide risk management and the role of the chief risk officer. white paper, ERisk. com, March, 25.

Li, Q., and Chipulu. 2014. Enterprise risk management and firm value within China's insurance industry: original research. Acta Commercii, 14(1): 1 - 10.

Lin, Y., Wen, and Yu. 2012. Enterprise risk management: Strategic antecedents, risk integration, and performance. North American Actuarial Journal, 16(1): 1-28.

Moeller, R. R. 2009. Brink's Modern Internal Auditing: A Common Body of Knowledge: John Wiley \& Sons.

Murhadi, W. R. 2008. Hubungan Capital Expenditure, Risiko Sistematis, Struktur Modal, Tingkat Kemampulabaan Terhadap Nilai Perusahaan. Manajemen \& Bisnis, 7 (1): 11-23.

Nuraina, E. 2012. Pengaruh Kepemilikan Institusional Dan Ukuran Perusahaan Terhadap Kebijakan Hutang Dan Nilai Perusahaan (Studi pada Perusahaan Manufaktur yang Terdaftar di BEI). Jurnal Bisnis dan Ekonomi, 19(2).

Pagach, D., and Warr. 2010. The effects of enterprise risk management on firm performance. Retrieved March, 9, 2010.

Prasetyorini, B. F. 2013. Pengaruh Ukuran Perusahaan, Leverage, Price Earning Ratio Dan Profitabilitas Terhadap Nilai Perusahaan. Jurnal Ilmu Manajemen (JIM), 1(1).

Ross, W. 2007. Pengantar keuangan perusahaan (8 ed.). Jakarta: Salemba Empat.

Sanjaya, C. K., dan Linawati. 2015. Pengaruh Penerapan Enterprise Risk Management dan Variabel Kontrol Terhadap Nilai Perusahaan di Sektor Keuangan. Finesta, 3(1): 52-57.

Siahaan, H. 2009. Manajemen Risiko pada Perusahaan dan Birokrasi. Jakarta: PT Gramedia.

Sudiyatno, B., dan Puspitasari. 2010. Tobin'sq Dan Altman Z-Score Sebagai Indikator Pengukuran Kinerja Perusahaan. Jurnal Ilmiah Kajian Akuntansi, 2(1).

Sugiyono. 2010. Metode penelitian kuantitatif kualitatif dan R\&D. Bandung: Alfabeta.

Sujoko, dan Soebiantoro. 2007. Pengaruh Struktur Kepemilikan Saham Leverage Faktor Intern Dan Faktor Ekstern Terhadap Nilai Perusahaan 
(Studi empirik pada perusahaan manufaktur dan non manufaktur di Bursa Efek Jakarta). Jurnal Manajemen dan Kewirausahaan, 9(1): 41-48.

Tahir, I. M., dan Razali. 2011. The Relationship between enterprise risk management (ERM) and firm value: Evidence From Malaysian public listed companies. Management, 1(2): 32-41.

Van, H., James, and Wahowicz. 2012. Prinsip-Prinsip Manajemen Keuangan Edisi 13 Buku 1: Terjemahan oleh Quratu'ain Mubarakah. Jakarta: Salemba Empat

Widjaya, P. E., dan Sugiarti. 2013. Penerapan Risk Management Untuk Meningkatkan Non-Financial Firm Performance Di Perusahaan Murni Jaya. Calyptra: Jurnal Ilmiah Mahasiswa Universitas Surabaya, 2(1). 